\title{
A PRIVATE CONSULTATION BY DR. WILLIAM HARVEY IN 1642
}

\author{
by
}

\begin{abstract}
JAMES ALSOP*
THIS NOTE is intended to draw attention to a previously unknown reference to William Harvey's private medical practice. The notice of a medical consultation by Harvey is recorded in a letter sent from London by Joseph Binnes to his cousin Joseph Colston in Italy. ${ }^{1}$ Both of these individuals were medical practitioners associated with St. Bartholomew's Hospital, where Harvey was physician from 1609 until 1643. Binnes had practised in London since at least $1633,{ }^{2}$ and was connected with St. Bartholomew's before his appointment as a surgeon in $1647 .{ }^{3} \mathrm{He}$ served until his death in May $1664 .{ }^{4}$ Colston had a family association with the hospital dating from $1608-25$ when John Colston was on the surgical staff, 5 and he rented his London residence from the hospital. 6 During his long absence from London in the 1640s while on the continent he was kept informed of events at St. Bartholomew's by Binnes and other correspondents. ${ }^{7}$ One of the purposes of Colston's travels was to study medicine at Padua University, where he graduated M.D. in December $1642 .{ }^{8} \mathrm{He}$ eventually returned to practise in London and became an honorary fellow of the Royal College of Physicians in 1664.9

The medical case involving Harvey which Binnes described to Colston was a personal one relating to one of Colston's relatives, the wife of Dr. Thomas Bennet.10 The Bennets were also connected with the London medical community and the family figures prominently in the affairs of Binnes and Colston. ${ }^{11}$ Binnes' letter is undated, but it can be fixed to the summer of 1642 by external evidence. ${ }^{12}$ Some additional details of

*James Alsop, Ph.D., Department of History, University College of North Wales, Bangor, Gwynedd LL57 2DG.

${ }^{1}$ Colston papers, British Library, Sloane MS. 118, fo. 69v.

${ }^{2} \mathrm{His}$ casebook for 1633-63 is in the British Library, Sloane MS. 153.

${ }^{3} \mathrm{He}$ was a personal friend of his predecessor John Pinder (1634-47): Pinder's will, Public Record Office, PROB 11/200, fos. 271-2; Sloane MS. 153, fos. 65, 151. For a business connexion with the hospital in 1642, see Sloane MS. 118, fo. 71.

${ }^{4}$ Norman Moore, The history of St. Bartholomew's Hospital, 2 vols., London, Pearson, 1918, vol. 2, p. 626; Victor C. Medvei and John Thornton (editors), The Royal Hospital of Saint Bartholomew, 1123-1973, London, St. Bartholomew's Hospital, 1974, p. 388.

SIbid., p. 388.

${ }^{6}$ This house in Little Britain was held by Colston in the period c. 1642-61: Sloane MS. 118, fos. 69, 103. 7Ibid., fos. 69-87. Colston was also friendly with John Pinder: ibid., fo. 69; PROB 11/200, fo. 271.

8 William Munk, The roll of the Royal College of Physicians of London, 3 vols., London, Royal College of Physicians, 1878 , vol. 1, p. 331 .

9Ibid. Colston's medical works in Latin and English are in Sloane MS. 118, fos. 160-314, and Sloane MS. 126.

10Sloane MS. 118, fo. 70.

${ }^{11}$ Ibid., fos. 63, 69, 70, 71, 81, 82, 86, 88; Sloane MS. 153, fos. 16v, 26v; Binnes' will, Public Record Office, PROB 11/313, fos. 358v-60; Munk, op.cit., note 8 above, vol. 1, p. 248 .

12It is written on the back of another letter to Colston from his aunt Ann Griffin, the two letters being sent together. She refers to letters from Colston recently received in June, dated in May at Rome: Sloane MS. 118 ,
\end{abstract}




\section{Short Articles}

the illness are contained in Binnes' medical record of the case, although this is incomplete and concludes before Dr. Harvey was consulted.13 Further information is found in a letter sent to Colston from London by Thomas Bennet on 14 July 1642 after his wife had been cured.14

The patient had a long history of illness due to hard swellings on her face caused initially, it was thought, by rotten teeth. ${ }^{15}$ She was repeatedly treated for this by Binnes from August 1640 with little success until two teeth were pulled in February and March of 1641.16 In May Binnes pronounced her cured, but the trouble soon reappeared. In late 1641 Mrs. Bennet had an abscess on her eyelid and shortly before Christmas she was touched by King Charles, apparently on the off-chance that this might help. ${ }^{17}$ However, her condition became serious when the swelling centred upon her temple. At this point two experts were consulted. The first was Edward Arris (d. 1676), the distinguished surgeon who founded his anatomy lectures in 1645.18 Arris was a governor of St. Bartholomew's and was well known to Joseph Binnes. 19 Binnes does not record Arris's opinion on the case, but he was apparently unhelpful and they immediately asked Dr. Harvey to see the patient. Harvey was pessimistic and feared that the swelling would prove cancerous. By this time the temple was exceedingly swollen and often fluctuating. Binnes wanted to open the abscess, but Mrs. Bennet was afraid and refused. Instead she wanted another opinion from a surgeon by the name of Mr. Fleete. He was called in and advised against opening the swelling, but after some disagreement Binnes prevailed and opened it. This operation was successful and Binnes dressed the temple every day, with Mr. Fleete assisting once or twice a week. By the beginning of May it was healed and the patient was well.

The illness was undoubtedly potentially very dangerous and Harvey was consulted because of his recognized medical knowledge. However, it is likely that Harvey only attended to Mrs. Bennet because he was personally acquainted with all concerned in the case, probably through their connexions with St. Bartholomew's Hospital. Although Harvey is reported progressively to have loosened his ties with the hospital after 1633,20 he continued to draw his salary until 1643 and it is apparent from this case that he was willing to help Binnes and Arris in early 1642. It is not known how close Binnes was to Harvey, although the former was later to serve as surgeon to the eminent physicians Sir Charles Scarburgh and Dr. John Bathurst, who were both Harvey's friends, ${ }^{21}$ and to work with them on cases. ${ }^{22}$ Harvey, himself, did not have a large role

fo. 69. From Colston's manuscript notes on his itinerary it is apparent that he was in Rome only in 1642: ibid., fos. 60-v. This date fits with other evidence: ibid., fo. 70; Sloane MS. 153, fos. 188v-9.

13 Ibid.

${ }^{14}$ Sloane MS. 118 , fo. 70 .

15 Ibid.

16Sloane MS. 153, fos. $188 \mathrm{v}-9$.

17Ibid.; Sloane MS. 118, fo. 69v.

18 Moore, op. cit., note 4 above, vol. 2, p. 626.

19Ibid., p. 233; Sloane MS. 153, fos. 40, 74v, 86. He was also acquainted with Binnes' friend and predecessor at St. Bartholomew's Hospital, John Pinder: PROB 11/200, fos. 271-2.

${ }^{20}$ Kenneth D. Keele, William Harvey, the man, the physician, and the scientist, London, Nelson, 1965, p. 70.

21Sloane MS. 153, fos. 54-v; Moore, op.cit., note 4 above, vol. 2, p. 495.

22Sloane MS. 153 , fo. $79 \mathrm{v}$. 


\section{News, Notes and Queries}

in Mrs. Bennet's illness, since it properly lay in the sphere of the surgeon, not the physician. However, the case does provide an example of his professional work in a period of his life when virtually nothing is known of his activities and movements. ${ }^{23}$

\footnotetext{
${ }^{23}$ Except for the knowledge that he was in London on 8 May 1641, nothing else is known of his activities from the beginning of that year until he went to Nottingham with King Charles I in August 1642: Louis Chauvois, William Harvey: his life and times: his discoveries: his methods, London, Hutchinson, 1957, pp. 141-142.
}

\section{News, Notes and Queries}

FIFTIETH ANNIVERSARY OF OSLER'S LIBRARY AT McGILL UNIVERSITY

On Tuesday, 29 May 1979, Oslerians and Oslerators travelled to Montreal to celebrate the fiftieth anniversary of the arrival at McGill of Osler's famous library. The day was dedicated to the book, not author nor owner, but the book as a physical object, to be described, analysed, and enumerated by the bibliographer and to be cherished and brought into the service of the student by the librarian.

Charles G. Roland, Professor of the History of Medicine at McMaster University, in his talk on "Osler and British Bibliography", after a good try, decided that bibliography is too difficult to define. Osler, a self-styled "dabbler" despite a sevenyear presidency of the Bibliographical Society, was much too interested in the book's content and its author, who readily joined the company of Osler's friends, living and dead. After doffing his cap to James Atkinson of York, whose "Medical Bibliography. A. and B." (1833) remains the only comic bibliography, Roland traced the inspiration for bibliography from Osler to Geoffrey Keynes, Harvey Cushing, and John Fulton. Osler did seek Carnegie support for a College of the Book to be founded at Johns Hopkins, where everything to do with the book could be taught and studied: the paper, the watermarks, the printing, and the publishing, and the techniques of book production analysed, an idea recently revived by Thomas Keyes. His idiosyncratic classification, embodied in the Bibliotheca Osleriana, completed by W. W. Francis, R. H. Hill, and Archibald Malloch and published in 1928, gave a logical structure to his library. The library was on view, not as Osler planned it and Bill Francis arranged it, although the original shelves remain. The books are now incorporated into the main medical library, a change which at its happening caused some adverse comment but which is now applauded as giving the books life and the library the chance to develop. So what might have been a frozen section has become a tissue culture.

Richard Durling, from the Christian-Albrechts-Universität, Kiel, brought Teutonic scholarship to bear on medieval manuscripts in the search for the ancestors, presumed lost, of all the old MS. Medical MS and archives can teach much about the status of the authors and their attitudes, for example their helplessness when faced with epidemics. 